\title{
Evaluation of Compressive strength and Workability of normal concrete, Temperature controlled (TC) concrete and emperature controlled self-compacted (TCSC) concrete.
}

\author{
${ }^{1}$ Er. Jatinder Kumar \& ${ }^{2}$ Er. Kshipra Kapoor \\ ${ }^{1}$ Research Scholar, Civil Engineering Department, Universal Institutions of Engineering \& Technology, Lalru \\ Mandi \\ ${ }^{2}$ Associate Professor, Civil Engineering Department, Universal Institutions of Engineering \& Technology, \\ Lalru Mandi
}

\begin{abstract}
The experiments conducted focuses on research to avoid shrinkage cranks and thermal expansion in concrete, the case study chosen for this experiment are underground structure having high rebar congestion. It became very critical while the mass or volume of concrete is more than natural. Generally the temperature controlled concrete for high mass or volume concrete. These type of structures are mainly foundations and under the ground only, where reinforcement area is very less and compared to concrete and concrete placing is also easy over there, but if the condition is not the same. When the situation is totally opposite of the assumption, the concrete to be done on height of more than 40 meter, and reinforcement volume is more and congestion is the condition can that concrete can't reach the bottom. Here the situation for which this paper is written. We expectingthe same situation, so our aim is to check the compressive strength and yield strength of normal concrete, Temperature controlled (TC) concrete and Temperature controlled self-compacted (TCSC) concrete.

Keywords:Temperature controlled (TC) concrete, Self-compacted Concrete (SCC), Temperature controlled self-compacted (TCSC) concrete, Strength of concrete.
\end{abstract}

\section{INTRODUCTION}

As the time going, the requirement of High raise Building, Heavy infrastructures likes, bridges, tunnels etc. is increasing day by day. All these big and heavy structures need strong, tough and huge foundations to complete the requirement of these structures. Generally heavy foundation in replaced by combination of two or more type of foundation like pile foundation and mat foundation or raft foundation system. But it's become tougher at those area, where SBC of foundation don't gives the minimum result for desired structure or the underground structure is not of the same nature throughout the layout. Sometime all condition match with the requirement, but the location of foundation is very much under and near to Water Level, where movement of underground structure is more than normal. So may be reason anyone from the above or it may be cost, which make the condition to use mass concrete in the foundation. As the mass concrete will give more heat of hydration, so control of temperature in concrete at the earlier stage become essential.
Temperature controlled (TC) concrete not only reduce the heat of hydration process but also decrease the shrinkage cracks and thermal expansions. Which not only increase the strength of concrete but also stability and life of structure.But when the condition came, where the temperature controlled concrete required, but the congestion of steel is too high to so that concrete cannot pass through easily to the bottom, then it's become the essential to provide the temperature controlled selfcompacted concrete, so that concrete can pass through all the congested area and give the required results

Experimental details:

Material Details:The list and details of material used in the experiment is listed below,

A. Cement: The Ordinary Portland cement (OPC) of 53 grade witch is completing the standard requirement of IS269:2015. The physical properties of cement checked as per IS:4031 (Part-2) -1999 (RA 2009), IS:4031 (Part-3 to 6)-1988 (RA 2009) and results area listed in Table-1. 
Er. Jatinder Kumar .et al. Int. Journal of Engineering Research and Application www.ijera.com ISSN : 2248-9622, Vol. 7, Issue 5, ( Part -4) May 2017, pp.26-33

\begin{tabular}{|c|l|c|l|}
\hline Sl. No. & Name of the test & Value & \multicolumn{1}{|c|}{$\begin{array}{c}\text { Requirement as per } \\
\text { IS: 12269 - 2013 }\end{array}$} \\
\hline 1 & Consistency & $29.50 \%$ & Not Specified \\
\hline 2 & Initial Setting Time & $145 \mathrm{~min}$ & Shal not be more than 600 Min. \\
\hline 3 & Final Setting Time & $205 \mathrm{~min}$ & Shal not be more than 600 Min. \\
\hline 4 & Specific gravity & 3.14 & \\
\hline 5 & Fineness of Cement & $302 \mathrm{~m}^{2} / \mathrm{Kg}$ & Shal not be less than $225 \mathrm{~m}^{2} / \mathrm{Kg}$ \\
\hline 6 & Soundness & $0.8 \mathrm{~mm}$ & Shal not be more than $10 \mathrm{~mm}$. \\
\hline \multirow{2}{*}{7} & Compressive Strength & & \\
\cline { 2 - 4 } & a. 7 Days & $47.0 \mathrm{Mpa}$ & Shal not be less than $37 \mathrm{Mpa}$ \\
\cline { 2 - 4 } & b. 28 Days & $62.5 \mathrm{Mpa}$ & Shal not be less than $53 \mathrm{Mpa}$ \\
\hline 8 & Density & $3.12 \mathrm{~g} / \mathrm{cc}$ & Not Specified \\
\hline
\end{tabular}

TABLE: 1(Physical - Properties of Cement)

The chemical properties of cement checked as per IS: 4032- 1985 (Reaffirmed 2009) and results are listed in Table-2

\begin{tabular}{|c|l|c|c|}
\hline $\begin{array}{c}\text { Sl. } \\
\text { No. }\end{array}$ & \multicolumn{1}{|c|}{ Test Conducted } & $\begin{array}{c}\text { Results } \\
(\boldsymbol{\%})\end{array}$ & $\begin{array}{c}\text { Requirement as per } \\
\text { IS:12269-2013 }\end{array}$ \\
\hline 1 & Total Loss on Ignition (\% by mas) & 2.89 & Not more than $4 \%$ \\
\hline 2 & Insoluble Residue (\% by mass), max & 2.87 & Not more than $4 \%$ \\
\hline 3 & $\begin{array}{l}\text { Ratio of \% of Lime to \% of silica, Alumina and } \\
\text { Iron Oxide as per the formula. }\end{array}$ & 0.89 & $\begin{array}{c}\text { Not greater than } 1.02 \\
\text { and not less than } 0.80\end{array}$ \\
\hline 4 & Ratio of \% of Alumina to Iron Oxide & 1.25 & Not less than 0.66 \\
\hline 5 & $\begin{array}{l}\text { Total Sulphur content calculated as sulphuric } \\
\text { anhydride }(\% \text { by mass) }\end{array}$ & 1.50 & Not more than $3.5 \%$ \\
\hline 6 & Magnesia $(\mathrm{MgO}) .(\%$ by mass) & 2.01 & Not more than $6 \%$ \\
\hline 7 & Tricalcium aluminate, $(\%$ by mass) & 6.76 & Not specified \\
\hline 8 & Chloride $(\mathrm{Cl}),(\%$ by mass) & 0.017 & Not more than $0.10 \%$ \\
\hline
\end{tabular}

TABLE: 2 (Chemical - Properties of Cement)

B. Fine aggregates: Crushed Sand has been brought from crusher yard (Uran, Maharashtra), fine aggregate passing through IS sieve, satisfying to grading Zone-II as per the IS: 383-2016 and details are listed in Table-3. The physical properties are listed in Table-4.

\begin{tabular}{|c|c|c|c|c|c|c|}
\hline \multirow{2}{*}{$\begin{array}{l}\text { Sl. } \\
\text { No. }\end{array}$} & \multirow{2}{*}{$\frac{\text { Sieve Size }}{\mathrm{mm}}$} & \multirow{2}{*}{$\frac{\% \text { Passing }}{\text { Crushed Sand }}$} & \multicolumn{4}{|c|}{ LIMITS AS PER IS 383-2016 } \\
\hline & & & ZONE I & ZONE II & ZONE III & ZONE IV \\
\hline 1 & 10.000 & 100.00 & 100 & 100 & 100 & 100 \\
\hline 2 & 4.500 & 99.70 & $90-100$ & $90-100$ & $90-100$ & $95-100$ \\
\hline 3 & 2.360 & 85.00 & $60-95$ & $75-100$ & $85-100$ & $95-100$ \\
\hline 4 & 1.180 & 52.60 & $30-70$ & $55-90$ & $75-100$ & $90-100$ \\
\hline 5 & 0.600 & 38.10 & $15-34$ & $35-59$ & $60-79$ & $80-100$ \\
\hline 6 & 0.300 & 25.60 & $5-20$ & $8-30$ & $12-40$ & $15-50$ \\
\hline 7 & 0.150 & 19.20 & $0-10$ & $0-10$ & $0-10$ & $0-15$ \\
\hline \multicolumn{2}{|c|}{ fineness Modulus } & 2.80 & \multicolumn{4}{|c|}{$\begin{array}{l}\text { Note - for crushed stone sands, the permissible limit on } \\
0.150 \mathrm{~mm} \text { sieve is increased to } 20 \%\end{array}$} \\
\hline
\end{tabular}

TABLE: 3 (Fine Aggregates - Sieve analysis report)

\begin{tabular}{|c|l|c|}
\hline SL. No. & \multicolumn{1}{|c|}{ Test Conducted } & $\begin{array}{c}\text { Result } \\
\text { (Crushed Sand) }\end{array}$ \\
\hline 1 & Specific Gravity & 2.79 \\
\hline 2 & Water Absorption (\%) & 2.41 \\
\hline 3 & Bulk density (kg/ litre) & 1.88 \\
\hline a. & Loose & 2.10 \\
\hline b. & Rodded & \\
\hline
\end{tabular}

TABLE: 4 (Fine Aggregates - Physical Test report) 
Er. Jatinder Kumar et al. Int. Journal of Engineering Research and Application www.ijera.com ISSN : 2248-9622, Vol. 7, Issue 5, ( Part -4) May 2017, pp.26-33

C. Course aggregates: Mechanically crushed angular granite stone of size $20 \mathrm{~mm}$ and $10 \mathrm{~mm}$ has been used, for different size of sieve used as per IS standard, which is maintained with different proportion of coarse aggregate and conforming to IS:383-2016 are listed in Table-5. The physical properties are listed in Table6.

\begin{tabular}{|c|c|c|c|c|c|}
\hline \multirow{2}{*}{$\begin{array}{l}\text { Sl. } \\
\text { No. }\end{array}$} & \multirow{2}{*}{$\begin{array}{c}\text { Sieve } \\
\text { Size } \\
\text { mm }\end{array}$} & \multicolumn{2}{|c|}{$\%$ Passing } & \multicolumn{2}{|c|}{$\begin{array}{c}\text { Limits as per IS-383-2016 } \\
\text { (single sized aggregate) }\end{array}$} \\
\hline & & $20 \mathrm{~mm}$ & $10 \mathrm{~mm}$ & $20 \mathrm{~mm}$ & $10 \mathrm{~mm}$ \\
\hline 1 & 40 & 100.00 & 100.00 & 100.00 & 100.00 \\
\hline 2 & 20 & 97.00 & 100.00 & $85-100$ & 100.00 \\
\hline 3 & 12.5 & 32.08 & 100.00 & - & 100.00 \\
\hline 4 & 10 & 7.80 & 85.75 & $0-20$ & $85-100$ \\
\hline 5 & 4.75 & 0.40 & 1.55 & $0-5$ & $0-20$ \\
\hline 6 & 2.36 & - & 1.27 & - & $0-5$ \\
\hline
\end{tabular}

TABLE: 5 (Course Aggregates - Sieve analysis report)

\begin{tabular}{|c|c|c|c|c|}
\hline \multirow{2}{*}{$\begin{array}{l}\text { SL. } \\
\text { No. }\end{array}$} & \multirow[t]{2}{*}{ Test Conducted } & \multicolumn{2}{|c|}{ Result } & \multirow{2}{*}{$\begin{array}{c}\text { Limits as per } \\
\text { IS-383-2016 }\end{array}$} \\
\hline & & $20 \mathrm{~mm}$ & $10 \mathbf{~ m m}$ & \\
\hline 1 & Specific Gravity & 2.86 & 2.85 & - \\
\hline 2 & Water Absorption (\%) & 1.33 & 1.44 & - \\
\hline 3 & $\begin{array}{l}\text { Aggregate Impact Value }(\%) \\
(12.5 \mathrm{~mm} \text { passing through } 10 \mathrm{~mm} \\
\text { retained })\end{array}$ & 13.2 & 16.6 & $\begin{array}{l}\text { Max. } 45 \% \text { non-wearing surface } \\
\text { Max. } 30 \% \text { wearing surface }\end{array}$ \\
\hline 4 & $\begin{array}{l}\text { Aggregate Crushing Value }(\%) \\
(12.5 \mathrm{~mm} \text { passing through } 10 \mathrm{~mm} \\
\text { retained) }\end{array}$ & 13.3 & 16.9 & Max. $30 \%$ wearing surface \\
\hline 5 & Bulk density (kg/ litre) & & & \\
\hline a. & Loose & 1.56 & 1.53 & - \\
\hline b. & Rodded & 1.69 & 1.65 & - \\
\hline 6 & Aggregate Abrasion Value (\%) & & & Max. 50\% non-wearing surface \\
\hline a. & Grading (B) & 13.3 & - & Max. $30 \%$ wearing surface \\
\hline b. & Grading (C) & - & 15.0 & \\
\hline 7 & Flakiness Index (\%) & 8.1 & 12.0 & Combined flakiness and elongation \\
\hline 8 & Elongation Index (\%) & 12.2 & 17.2 & index shall not be exceed $40 \%$ \\
\hline
\end{tabular}

\section{TABLE: 6 (Course Aggregates - Physical Test report)}

D. Chemical admixtures: Polycarboxylate ether based super-plasticizer condensate as high range water reducing admixture (HRWR) to maintain a satisfactory of workability for different mixes with constant w/b ratio throughout the experimental works. The chemical analysis report is listed in Table-7.

\begin{tabular}{|c|c|c|c|c|c|}
\hline $\begin{array}{l}\text { Sl. } \\
\text { No. }\end{array}$ & $\begin{array}{c}\text { TEST } \\
\text { CONDUCTED }\end{array}$ & Results & $\begin{array}{c}\text { Requirements (as per } \\
\text { IS:9103-1999 (RA:2013) } \\
\text { Table-2) } \\
\end{array}$ & Test Method & Conformity \\
\hline 1 & $\begin{array}{l}\text { Dry Material } \\
\text { Content, \% by } \\
\text { mass }\end{array}$ & 31.27 & $\pm 5 \%$ of declared Value & $\begin{array}{c}\text { IS:9103:1999 } \\
\text { (RA:2013) Clause.10.1 } \\
\text { ANNEX E-1 }\end{array}$ & - \\
\hline 2 & $\begin{array}{c}\text { Asha Content, } \% \\
\text { by mass }\end{array}$ & 0.48 & $\pm 5 \%$ of declared Value & $\begin{array}{c}\text { IS:9103:1999 } \\
\text { (RA:2013) Clause.10.1 } \\
\text { ANNEX E-2 }\end{array}$ & - \\
\hline 3 & $\begin{array}{c}\text { Relative Density } \\
\text { at } 25^{\circ} \mathrm{C}\end{array}$ & 1.105 & $\pm 0.02 \%$ of declared Value & $\begin{array}{c}\text { IS:9103:1999 } \\
\text { (RA:2013) Clause.10.1 } \\
\text { ANNEX E-3.1(b) }\end{array}$ & - \\
\hline 4 & $\begin{array}{c}\text { Chloride (as } \mathrm{Cl} \text { ). } \\
\% \text { by mass }\end{array}$ & 0.012 & $\pm 10 \%$ of declared Value & $\begin{array}{c}\text { IS:6925-1973 (RA- } \\
\text { 2008) } \\
\text { Clause;5.0 } \\
\end{array}$ & - \\
\hline 5 & $\mathrm{pH}$ Value at $25^{\circ} \mathrm{C}$ & 6.21 & 6.0 Minimum & $\begin{array}{c}\text { IS:9103:1999 } \\
\text { (RA:2013) Clause. } 10.1 \\
\text { ANNEX E-5 }\end{array}$ & Yes \\
\hline
\end{tabular}

TABLE: 7 (Admixture - Chemical Analysis/ Test report) 
E. Water and Ice: The type of water used for the concrete mix will affect the properties of concrete. So before starting the production of concrete, the physical as well as chemical properties to be check. And when the case arrived for temperature controlled concrete, then become essential to check all factor as per IS code 7861 (Part-1)-1975 to control the temperature of concrete mix. The quantity of ice used for lowering the

temperature is calculated as per IS code 7861 (Part1)- 1975 recommendation and explained below:

Calculation for Ice (to find the quantity of ice to be added in concrete to produce the concrete as per targeted Temperature aggregate): As per IS: 7861 (Part-I) - 1975, the calculation of ice requirement to produce the concrete targeted temperature can be calculated.

As per equation 6.2.b (from IS: 7861 (Part-I) 1975).

$$
\mathbf{T}=\frac{\mathrm{S}(\mathrm{TaWa}+\mathrm{TcWc})}{\mathrm{S}(\mathrm{Wa}+\mathrm{Wc})+\mathrm{Ww}+\mathrm{Wi}+\mathrm{Wwa}}+\frac{(\mathrm{Ww}-\mathrm{Wi}) \mathrm{Tw}+\mathrm{Wwa} \text { Twa }-79.6 \mathrm{Wi}}{\mathrm{S}(\mathrm{Wa}+\mathrm{Wc})+\mathrm{Ww}+\mathrm{Wi}+\mathrm{Wwa}}
$$

Where

$\mathrm{T}$

Ta, Tc, Tw, Twa
$=$ Temperature of freshly mixed concrete $\left({ }^{\circ} \mathrm{C}\right)$;

$=$ Temperature of aggregate, cement, added mixing water, free

water on aggregate respectively $\left({ }^{\circ} \mathrm{C}\right)$;

$\mathrm{Wa}, \mathrm{Wc}, \mathrm{Ww}, \mathrm{Wwa}, \mathrm{Wi}$ = mass of aggregate, cement, added mixing water, free water on aggregate and ice respectively $(\mathrm{Kg})$; S

$=$ Specific heat of cement and aggregate. (As per IS code it can be taken as 0.22 )

Situation- 1 (For M50TC Concrete): As per above equation, the ice requirement will be calculated as per calculated data;

$$
\begin{array}{llll}
\mathrm{T}^{*}=19^{\circ} \mathrm{C}, & \mathrm{Ta}=36^{\circ} \mathrm{C}, & \mathrm{Tc}=45^{\circ} \mathrm{C}, & \mathrm{Tw}=14^{\circ} \mathrm{C} \\
\mathrm{Wa}=1880, & \mathrm{Wc}=513, & \mathrm{Ww}=149, & \mathrm{Wwa}=0^{* *}, \quad \mathrm{Wi}=\text { to be identified }
\end{array}
$$

$* \mathrm{~T}=$ Targeted Temperature (as the temperature required during placing of concrete is $21^{\circ} \mathrm{C}$ )

**Wwa taken as zero, as no water sprinkled over aggregate.

$19=\frac{0.22(36 \times 1880+45 \times 513)+(149-\mathrm{Wi}) 14-79.6 \mathrm{Wi}}{0.22(1880+513)+149+\mathrm{Wi}}$

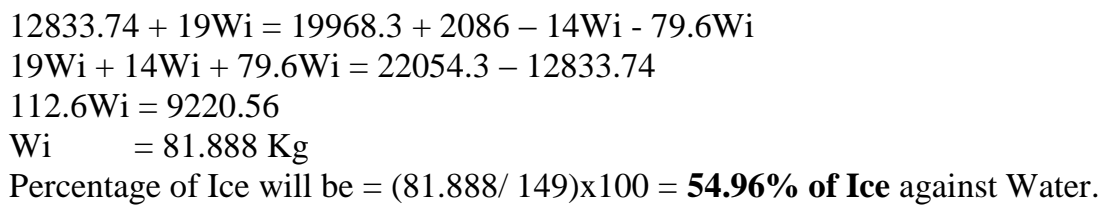

Situation- 2 (For M50SCTC Concrete): As per above equation, the ice requirement will be calculated as per calculated data;

$$
\begin{array}{llll}
\mathrm{T}^{*}=19^{\circ} \mathrm{C}, & \mathrm{Ta}=36^{\circ} \mathrm{C}, & \mathrm{Tc}=45^{\circ} \mathrm{C}, & \mathrm{Tw}=14^{\circ} \mathrm{C} \\
\mathrm{Wa}=1663, & \mathrm{Wc}=595, & \mathrm{Ww}=195, & \mathrm{Wwa}=0^{* *}, \quad \mathrm{Wi}=\text { to be identified }
\end{array}
$$

$* \mathrm{~T}=$ Targeted Temperature (as the temperature required during placing of concrete is $21^{\circ} \mathrm{C}$ )

**Wwa taken as zero, as no water sprinkled over aggregate.

$19=\frac{0.22(36 \times 1663+45 \times 595)+(195-\mathrm{Wi}) 14-79.6 \mathrm{Wi}}{0.22(1663+595)+195+\mathrm{Wi}}$

$13143.44+19 \mathrm{Wi}=19061.46+2730-14 \mathrm{Wi}-79.6 \mathrm{Wi}$

$19 \mathrm{Wi}+14 \mathrm{Wi}+79.6 \mathrm{Wi}=21791.46-13143.44$

$112.6 \mathrm{Wi}=8648.02$ 
$\mathrm{Wi} \quad=76.80 \mathrm{Kg}$

Percentage of Ice will be $=(76.80 / 195) \times 100=\mathbf{3 9 . 3 9 \%}$ of Ice against Water

Calculation for Ice (to reduce the water temperature from natural temperature): To reduce the existing temperature of water which is $26^{\circ} \mathrm{C}$ to $14^{\circ} \mathrm{C}$, calculate for ice requirement the following equations has performed.

Situation- 1 (For M50TC Concrete):

To cool $1 \mathrm{~g}$ of water by $1^{\circ} \mathrm{C}$ required $\quad=4.186$ Joule to be removed

So $(149-81.88) \mathrm{Kg}$ of water by $12^{\circ} \mathrm{C}$ required $=4.186 \times 12 \times 67.12 \times 1000$

$=3371571.84$ Joule to be removed

This energy is then used to melt ice.

Heat of fusion of ice

$=333.55 \mathrm{~J} / \mathrm{g}$ or $0.33355 \mathrm{~kJ} / \mathrm{g}$ of ice

So to change 3371571.84 joule to change $=3371571.84 / 333.55$

$=10108 \mathrm{~g}$ or $10.11 \mathrm{~kg}$ of ice

Situation- 2 (For M50SCTC Concrete):

To cool $1 \mathrm{~g}$ of water by $1^{\circ} \mathrm{C}$ required $=4.186$ Joule to be removed

So $(195-76.8) \mathrm{Kg}$ of water by $12^{\circ} \mathrm{C}$ required $=4.186 \times 12 \times 118.2 \times 1000$

$=5937422.4$ Joule to be removed

This energy is then used to melt ice.

Heat of fusion of ice

$=333.55 \mathrm{~J} / \mathrm{g}$ or $0.33355 \mathrm{~kJ} / \mathrm{g}$ of ice

So to change 5937422.4 joule to change $=5937422.4 / 333.55$

\section{$=17800 \mathrm{~g}$ or $17.8 \mathrm{~kg}$ of ice}

F. Concrete Mixture proportion and casting of specimens: The mix is designed with the guideline given in IS: 10262:2009 and with the help of ACI-211.1-91. All the details and proportion provided in Table-8. A total of 3 different concrete mixtures were proportioned based on practical requirement of materials. For temperature controlled concrete, Ice is added to water to lower the temperature from its natural temperature level. The concrete mixtures were mixed using 50 litres capacity Pan Mixer (shown in Fig-1) and specimens were casted by using the steel mould of standard cube 150x150x150mm ( 3 cubes of each mix design). The fresh concrete mixtures in moulds were compacted using table vibrator and the specimens were remoulded after 24 hours after casting and water cured at $27 \pm 3^{\circ} \mathrm{C}$ until the age of testing at 7 and 28 days as shown in figure 2 .

\begin{tabular}{|c|c|c|c|c|c|}
\hline \multirow{2}{*}{$\begin{array}{c}\text { Sl. } \\
\text { No. }\end{array}$} & \multirow{2}{*}{ MATERIAL DESCRIPTION } & \multicolumn{3}{c|}{ CONCRETE MIX DETAILS } \\
\cline { 3 - 6 } & \multicolumn{2}{|c|}{ CEMENT (in Kg) } & 450 & 213 & 450 \\
\hline 1 & \multicolumn{2}{|c|}{ FLY ASH } & 120 & 0 & 0 \\
\hline 2 & \multicolumn{2}{|c|}{ GGBS } & 0 & 300 & 145 \\
\hline 3 & \multicolumn{2}{|c|}{ C. sand } & 653 & 837 & 1031 \\
\hline 4 & \multirow{2}{*}{5} & $10 \mathrm{~mm}$ & 539 & 522 & 632 \\
\cline { 3 - 6 } 5 & \multirow{2}{*}{ AGGREGATE } & $20 \mathrm{~mm}$ & 500 & 521 & 0 \\
\hline 6 & \multicolumn{2}{|c|}{ WATER (in Litre) } & 165 & 149 & 175 \\
\hline \multirow{2}{*}{7} & \multirow{2}{*}{ ADMIXTURE } & QTY. & 3.99 & 5.64 & 5.95 \\
\cline { 3 - 6 } & \multicolumn{2}{|c|}{ PERCENTAGE } & $0.70 \%$ & $1.10 \%$ & $1 \%$ \\
\hline
\end{tabular}

TABLE: 8 - Mix Proportions (Value for 1 cu-m of Concrete) 


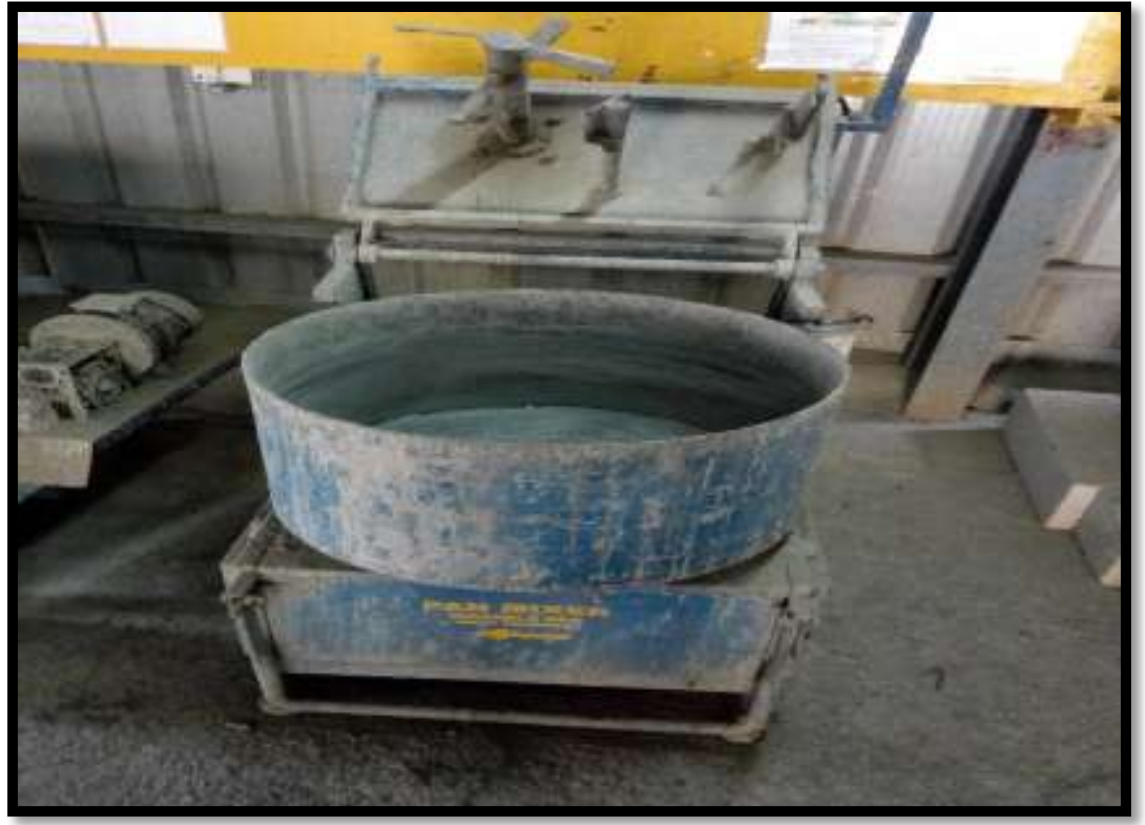

Fig-1: Pan Mixer (Experimental Setup for Concrete Mixing)

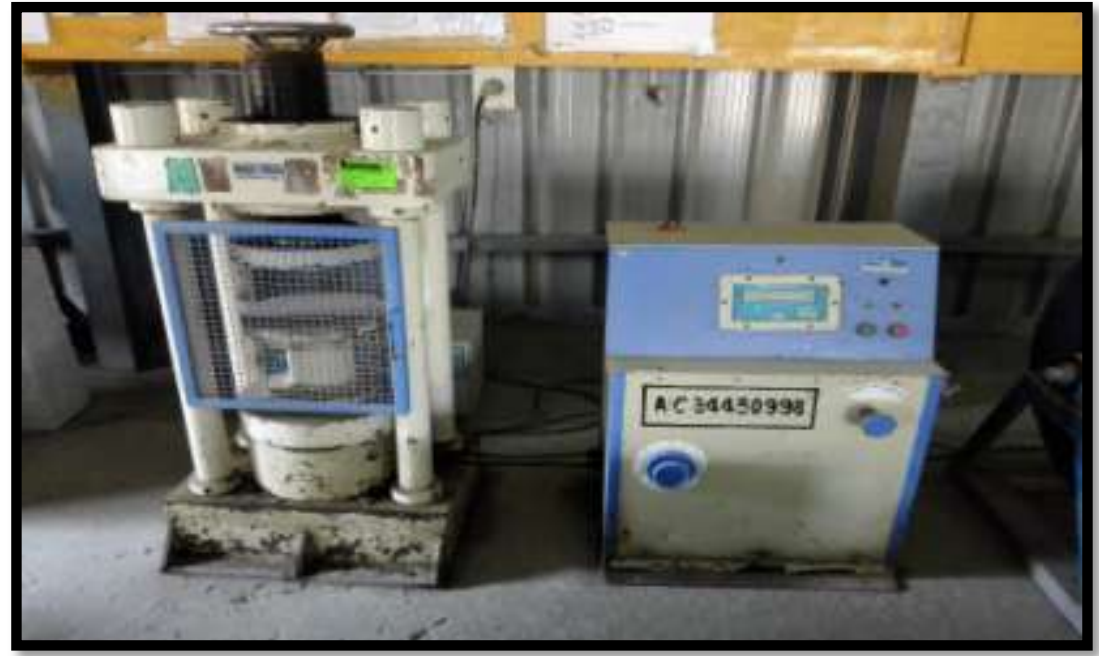

Fig-2: Experimental Setup for Compressive test

Experimental Test Results and Discussion

A. Compressive Strength: The concrete compressive strength can be achieved fully by replacing the partial percentage of cement, which not only the temperature of concrete during the process of heat of hydration but also provide the desired results. The result shown in the Table-9 to confirm the above statement.

\begin{tabular}{|c|c|c|c|}
\hline Concrete Mix & Mix ID & 7 DAYS & 28 DAYS \\
\hline \multirow{3}{*}{ M50 - NC } & M1 & 41.20 & 59.15 \\
\cline { 2 - 4 } & M2 & 43.50 & 63.80 \\
\cline { 2 - 4 } & M3 & 42.95 & 60.35 \\
\hline \multirow{3}{*}{ M50-TCC } & M4 & 32.05 & 51.50 \\
\cline { 2 - 4 } & M5 & 30.90 & 50.65 \\
\cline { 2 - 4 } & M6 & 32.35 & 49.75 \\
\hline \multirow{3}{*}{ M50-TCSCC } & M7 & 33.95 & 50.90 \\
\cline { 2 - 4 } & M8 & 30.90 & 49.45 \\
\cline { 2 - 4 } & M9 & & 50.05 \\
\hline
\end{tabular}

TABLE: 9 - Compressive Strength in MPa 
Er. Jatinder Kumar et al. Int. Journal of Engineering Research and Application www.ijera.com ISSN : 2248-9622, Vol. 7, Issue 5, ( Part -4) May 2017, pp.26-33

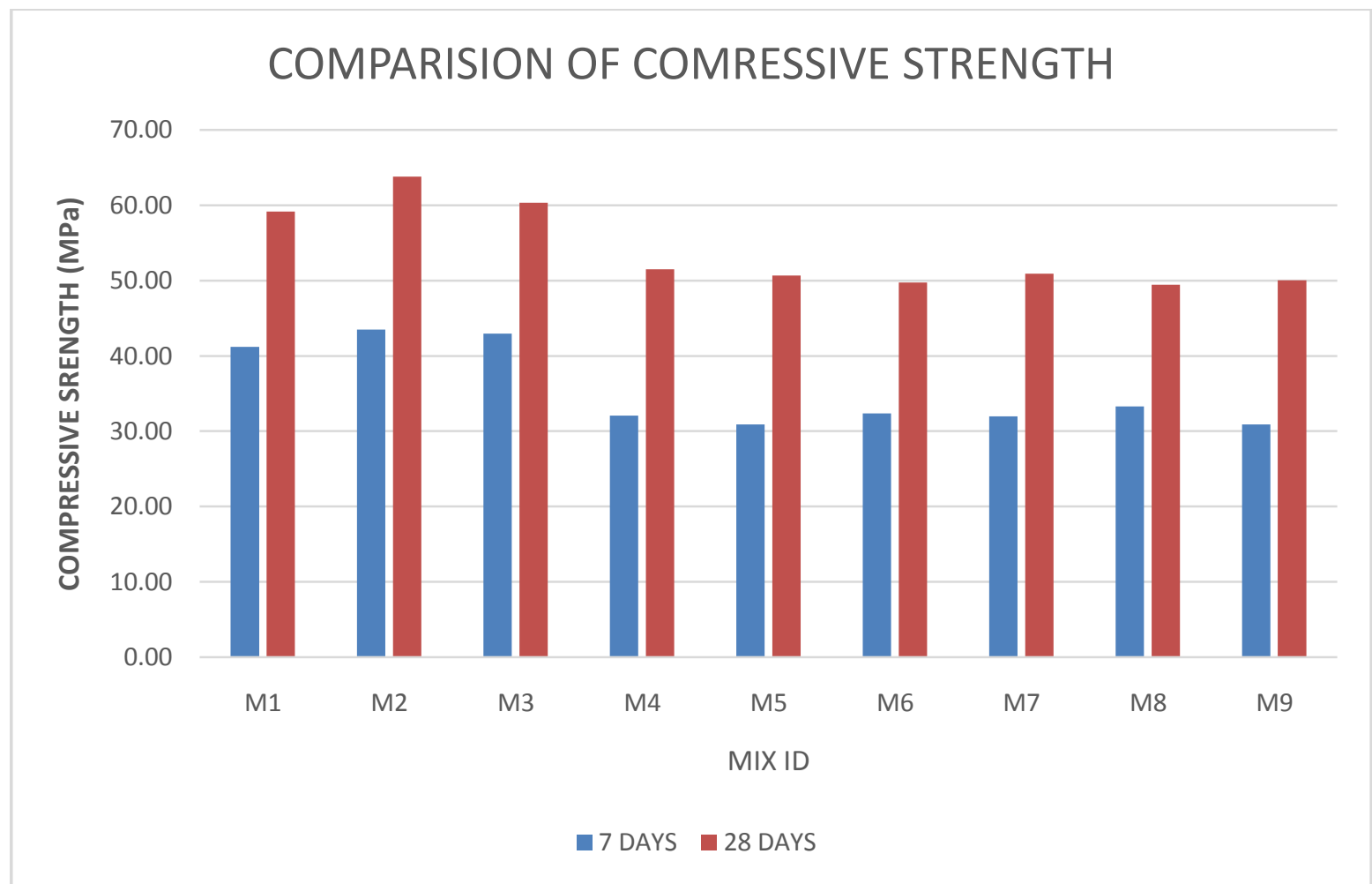

Fig-3: Comparison of Compressive Strength

B. WORKABILITY: The Increase in percentage of fine aggregates without increasing the percentage of admixture but by reducing the percentage of GGBS and increase the cement content will provide the great flow table which shows the increment in the workability and give the confirmation of self-compaction. The same has been found in laboratory result and listed in the final result table- 9 .

\begin{tabular}{|c|c|c|c|c|c|c|}
\hline $\begin{array}{l}\text { S } \\
\mathbf{N}\end{array}$ & & \multicolumn{2}{|c|}{ DESCRIPTION } & $\begin{array}{l}\text { NORMAL } \\
\text { CONCRETE }\end{array}$ & $\begin{array}{l}\text { TEMPERATURE } \\
\text { CONTROLLED } \\
\text { CONCRETE }\end{array}$ & $\begin{array}{l}\text { TEMPERATURE } \\
\text { CONTROLLED } \\
\text { SELF } \\
\text { COMPACTED } \\
\text { CONCRETE }\end{array}$ \\
\hline 1 & & \multicolumn{2}{|l|}{ Grade of Concrete } & M50 & M50 & M50 \\
\hline 2 & & \multicolumn{2}{|l|}{ Flow Table } & 550 & 510 & 650 \\
\hline \multirow{3}{*}{3} & 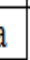 & \multirow{3}{*}{ Temperature (in ${ }^{\circ} \mathrm{c}$ ) } & at the time of mixing & 37 & 19 & 19 \\
\hline & ) & & $\begin{array}{l}\text { at the time of } \\
\text { Transportation }\end{array}$ & 38 & 20 & 20 \\
\hline & 2 & & at the time of Placing & 39 & 21 & 21 \\
\hline \multirow[b]{2}{*}{4} & 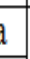 & \multirow{2}{*}{$\begin{array}{l}\text { Compressive } \\
\text { Strength } \\
\text { (in } \mathrm{MPa} \text { ) } \\
\end{array}$} & 7Days & 42.55 & 31.77 & 32.05 \\
\hline & 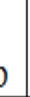 & & 28 Days & 61.10 & 50.63 & 50.15 \\
\hline
\end{tabular}

TABLE: 8 - Final Report Card 


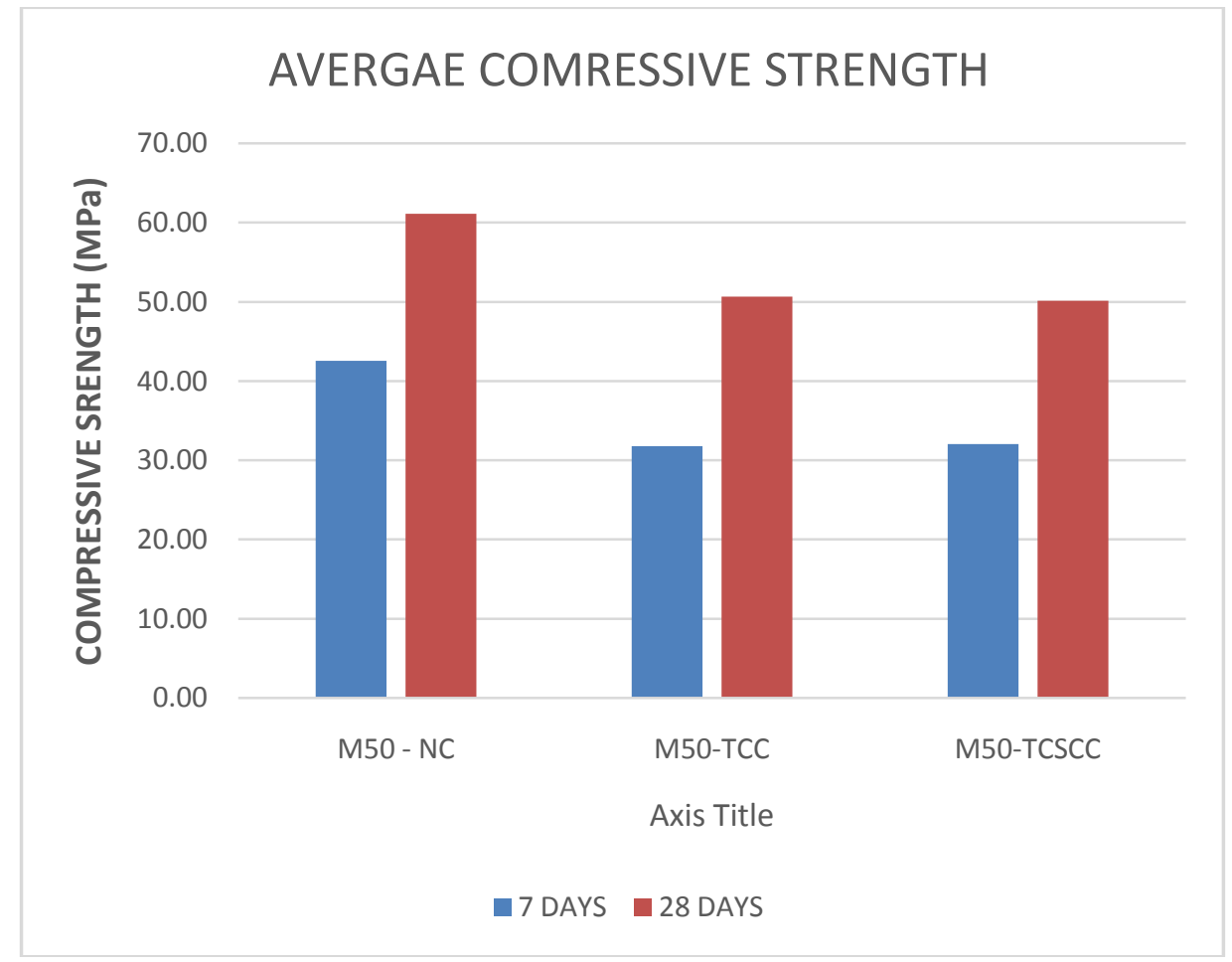

Fig-4: Comparison of Average- Compressive Strength

\section{CONCLUSIONS}

Based on the research study the following conclusion are drawn from the test results:-

$>$ The compressive strength developed in TC concrete is slow. So where the early strength required, this concrete will not give desired result.

$>$ These type of concrete cannot be used for PT structures as desired can be achieved only on 56 days compressive strength chart.

$>$ The temperature control of concrete can be achieved by partial replacement of cement with GGBS.

$>$ The addition of ice in water instead of adding ice in concrete, just before adding water into mix will reduce the effect on compressive strength of concrete.

$>$ GGBS is not only reduce the requirement of cement content but also provide great help in reducing the temperature of concrete during hardening stage.

$>$ For self-compacted temperature controlled concrete, the GGBS quantity should by less with respect to cement to achieve the desired compressive strength.

\section{REFERENCES}

[1]. IS: 269:2015, Ordinary Portland Cement Specification.

[2]. IS: 4031 (Part-2) -1999 (RA 2009), Methods of Physical Tests for Hydraulic Cement.
Part-2 Determination of fineness by Blaine Air Permeability Method.

[3]. IS: 4031 (Part-3 to 6)-1988 (RA 2009), Methods of Physical Tests for Hydraulic Cement. Part-3 Determination of Soundness, Part-4 Determination of consistency of standard cement paste, Part-5 Determination of initial and final setting times, Part-6 Determination of compressive strength of hydraulic cement other than masonry cement.

[4]. IS: 4032- 1985 (Reaffirmed 2009), Method of chemical analysis of hydraulic cement.

[5]. IS: 383-2016, Specification for coarse and fine aggregate from natural sources for concrete.

[6]. IS:9103-1999 (RA:2013), Concrete Admixture - Specification.

[7]. IS: 456: 2000 (Reaffirmed 2005), Plain and Reinforced concrete - Code of Practice (Fourth Revision) (Tenth Reprint April 2007 - including amendments 1 and 2 )

[8]. IS: 7861 (Part-1)-1975, Code of Practice for Extreme Weather Concreting, Part-I recommended for Hot Weather Concreting.

[9]. IS: 10262:2009, Concrete Mix Proportioning - Guideline (First Revision).

[10]. ACI-211.1-91, standard practice for selecting proportion for normal, heavyweight and mass concrete (ACI-211.191) reapproved 1997. 